\title{
The Influence Of Financial Flexibility, Managerial Ownership, Firm Size On Capital Structure, And Firm Value On Infrastructure, Utility, And Transportation Companies.
}

\author{
${ }^{1}$ Asrul Jaya, ${ }^{2}$ Djabir Hamzah, ${ }^{3}$ Maat Pono, ${ }^{4}$ Idayanti Nursyamsi \\ ${ }^{1,2,3,4}$ Master in Management Science, Faculty of Economics and Business,Hasanuddin University \\ *Corresponfing author : \\ Email : asrul469@gmail.com
}

\begin{abstract}
This study aims to analyze the effect of financial flexibility, managerial ownership, and firm size on firm value with capital structure as an intervening variable for infrastructure, utility, and transportation companies.This research was a quantitative study. The data used were secondary data in the form financial statements of infrastructure, utility and transportation companies listed in the Indonesia Stock Exchange during the period 2015-2019. The sample used was a purposive sampling technique consisting of 30 companies infrastructure, utility and transportation. The data were analyzed using path analysis supported by SmartPLS 3.3 software.The results show that financial flexibility has no significant negative effect on the capital structure; managerial ownership has a significant negative effect on the capital structure; firm size has a significant positive effect on the capital structure; financial flexibility has a significant negative effect on firm value; managerial ownership has no significant positive effect on firm value; firm size has no significant positive effect on firm value; capital structure has a significant positive effect on firm value; financial flexibility had no significant effect on firm value through capital structure; managerial ownership has a significant effect on firm value through capital structure; firm size has a significant effect on firm value through capital structure.
\end{abstract}

Keywords: Financial Flexibility, Managerial Ownership, Firm Size, Firm Value

\section{INTRODUCTION}

The industrial revolution 4.0 is marked by the vuca era as the new norm that applies and this trend is discussed in the face of global competition. VUCA is an acronym for Volatile (turbulent), Uncertain (uncertain), Complex (complex), and Ambigue (unclear), (Aribowo \& Wirapraja, 2018). The world today is a complex system and it changes rapidly among its sub-systems, therefore pressure is applied to make every effort to anticipate any changes and forms of transformation. Although everyone feels that the impact of Covid-19 has led to an economic and business crisis, pandemics are nothing new in the VUCA world as experts repeatedly tell us to be prepared for changes that will always exist. Covid-19 is a disaster that must be faced in today's VUCA world (Huy,2020).

According to the Central Statistics Agency (BPS), there was a minus 3.49\% economic growth in the third quarter of 2020 (year on year/yoy ) in Indonesia leading to a recession zone as indicated by the contraction of two consecutive quarters. The basis for the establishment of the company was to maximize the profits to be received, prosper the owners and optimize the firm value as reflected in its share price (Martono, and Harjito, 2005). For go public companies, maximizing firm value can be translated by maximizing stock prices (Sudana, 2011). The Covid-19 pandemic has also reduced capital flows in several countries due to the panic that reduces the level of market confidence, especially in countries that are slow to stop the spread of the virus (Baldwin \& Di Mauro, 2020). However, the efforts made by the company to maximize the firm value are to optimize its capital structure and minimize risk, therefore investors can respond positively. The new capital structure is stated to be optimal if there is a combination of debt and capital to maximize the company's stock price (Brigham, 2011). However, the problem in the capital structure in the vuca era and covid-19 pandemic is the company's level of capability to meet the flow of funds used for operations and sustainability. Optimally, the capital structure has an impact on increasing the 
company's stock price, therefore the company must be able to examine the elements of the capital structure (Keown, 2010).

Consequently, maintenance of the company's financial flexibility is a way to survive and sustain in the pandemic era. Naturally, the COVID-19 shock presented a loss of cash flow of indeterminate duration for companies, therefore Financial flexibility plays an important role in strategic adjustment especially in an uncertain environment (Teng et al., 2021). An increased firm value can be achieved if there is a cooperation between company management and other parties including shareholders and stakeholders. The firm value must consider all stakeholder groups, not only shareholders (Bilyay-Erdogan, 2020), hence the firm size plays an important role in optimizing firm value.

According to Andriza \& Yusra (2019), the firm value indicates the company's financial strength in supporting its performance. The sectors most affected by the COVID-19 pandemic in the VUCA era include the infrastructure, utilities, and transportation sectors and the company affected is Garuda Indonesia. Furthermore, the shares of PT Garuda Indonesia (Persero) Tbk. (GIAA) based on Indopremier data, GIAA's share price recorded Rp440 at the beginning of this year and then dropped to a level of Rp. 240 as of June 2021 (www.katadata.co.id,2021). This indicated a decline in the value of the Garuda Indonesia company due to the shock of the Covid-19 pandemic. The study aims to examine the dependent variable of financial flexibility, managerial ownership, firm size, the independent variable of firm value, and the intervening variable of the capital structure, therefore looking at the impact of the vuca era and covid-19 pandemic on firm value. Furthermore, there is a lack of study that discusses financial flexibility, as well as those who study using this model.

The framework of thinking in this study may be summarized as follows :

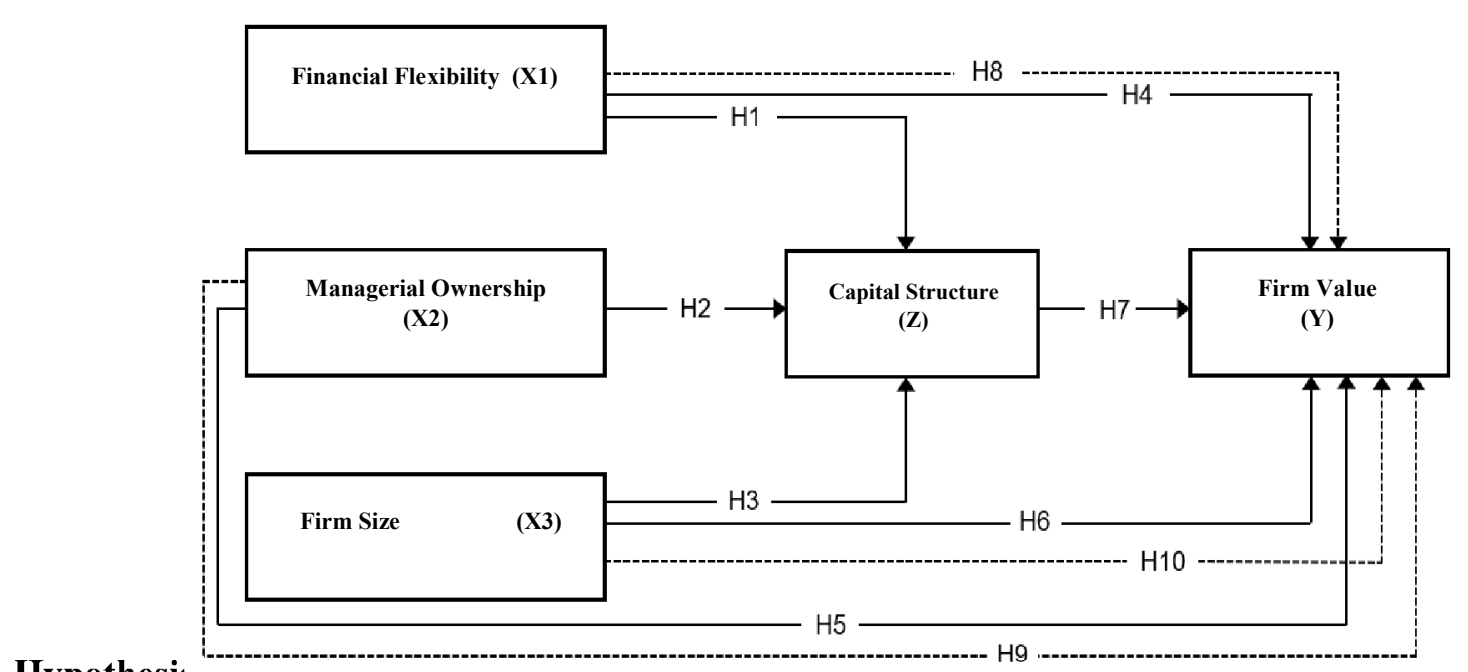

\section{Hypothesi:}

This study examınes the eftect of tınancial tlexıbılıty, managerıal ownershıp, the tırm size on capital structure and firm value. The following hypotheses are described:

H1: Financial Flexibility significantly affected on capital structure.

H2: Managerial ownership significantly affected on capital structure.

H3: Firm size significantly affected on capital structure.

H4: Financial Flexibility significantly affected on firm value.

H5: Managerial Ownership significantly affected on firm value.

H6: Firm size significantly affected on firm value.

H7: Capital structure significantly affected on firm value.

H8: Financial Flexibility significantly affected on firm value through capital structure

H9: Managerial ownership significantly affected on firm value through capital structure.

H10: Firm size significantly affected on firm value through capital structure. 


\section{METHODS}

\section{Location}

This study uses a quantitative approach and the location is infrastructure, utility, and transportation companies listed on the Indonesia Stock Exchange in 2015-2019.

\section{Population and Sample}

The population in this study are infrastructure, utility, and transportation companies listed on the Indonesia Stock Exchange for the 2015-2019 period. A total of 30 companies were used as samples using the purposive sampling technique.

\section{Data Types and Sources}

The type of data used in this study is quantitative with secondary data sources derived from financial statements.

\section{Data analysis}

The data analysis in this study includes data processing, data organization, and finding results. The analysis technique involves path analysis which is applied to SmartPLS 3.3. Furthermore, path analysis can be used to estimate the direct, indirect, and total effects between variables in the model (Wright, 1934). The structural equations depicted by path diagrams are considered to be representations of the theory, hence the relationship between latent variables is a manifestation of the theory.

The variables in this study and their measurements are presented in Table 2. It can be seen that all research variables are ratio scale data.

Table 1. Variable Measurement

\begin{tabular}{|l|l|l|l|}
\hline No & \multicolumn{1}{|c|}{ Variable } & \multicolumn{1}{|c|}{ Measurement } & Scale \\
\hline 1. & $\begin{array}{l}\text { Financial Flexibility } \\
\text { (X1) }\end{array}$ & MCOV : Cash / Market Value & Ratio \\
\hline 2. & Managerial Ownership (X2) & $\begin{array}{l}\text { Proportion of shares owned / total number } \\
\text { of shares }\end{array}$ & Ratio \\
\hline 3. & Firm Size (X3) & Log Natural Total Assets & Ratio \\
\hline 4. & Capital Structure (Z) & Total Debt / Total Equity & Ratio \\
\hline 5. & Firm Value (Y) & $\begin{array}{l}\text { Shares Market Price / Book Value per } \\
\text { share }\end{array}$ & \\
\hline
\end{tabular}

\section{RESULTS AND DISCUSSION}

\section{Measurement Evaluation (Outer Model)}

The external model analysis determines the relationship between latent variables and their indicators. Tests carried out on the external model is Convergent Validity. The convergent validity is the loading factor value on the latent variable with its indicators. The expected value is above 0.7 .

Table 2. Outer Loading Test

\begin{tabular}{|l|c|c|}
\hline & Outer Loading & Result \\
\hline Financial Flexibility & 1.000 & Valid \\
\hline $\begin{array}{l}\text { Managerial } \\
\text { Ownership }\end{array}$ & 1.000 & Valid \\
\hline Firm Size & 1.000 & Valid \\
\hline Capital Structure & 1.000 & Valid \\
\hline Firm Value & 1.000 & Valid \\
\hline
\end{tabular}

Source: SmartPLS data processing result, 2021

Table 1 shows that the outer loading $>0.7$ which means that the variables financial flexibility, managerial ownership, firm size, capital structure and firm value are feasible and valid for used in research. 


\section{Structural Model Evaluation}

After the measurement model is checked and fulfilled, the next step is to evaluate the structural model.

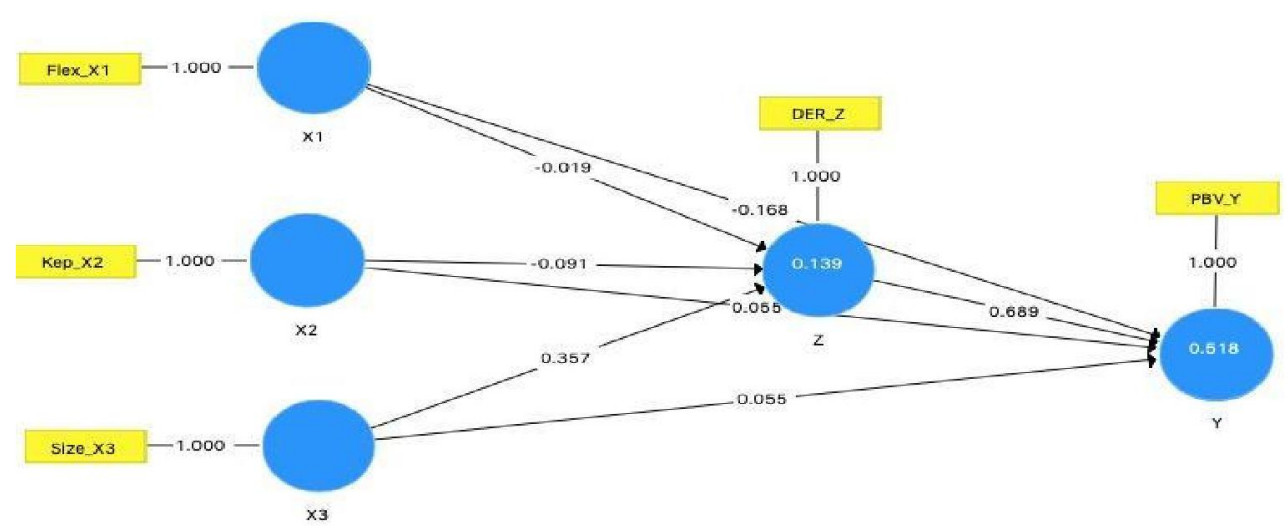

Fig 1. Structural Equation

$\mathrm{Y}=\mathbf{- 0 , 1 6 8}+\mathbf{0 , 0 5 5}+\mathbf{0 , 0 5 5}+\mathbf{1}$

$\mathrm{Z}=\mathbf{- 0 , 0 1 9}-\mathbf{0 , 0 9 1}+\mathbf{0 , 3 5 7 + 1}$

\section{Structural Model (Inner Model)}

Table 3. R Square Value

\begin{tabular}{|c|c|c|}
\hline & R Square & R Square Adjusted \\
\hline Firm Value & 0,518 & 0,505 \\
\hline Capital Structure & 0,139 & 0,121 \\
\hline
\end{tabular}

Source: SmartPLS data processing result, 2021

Based on the coefficient of determination test table above, the R- Square for the firm value is 0.518 . The result showed that the variables of financial flexibility, managerial ownership, and firm size are simultaneously able to explain the firm value variable by $51 \%$ and the remaining $49 \%$ is explained by other variables not included in the model. Also, the value obtained for the R-Square of firm value is within the moderate to strong category (Chin, 1998). Consequently, this means that the independent variables namely financial flexibility, managerial ownership and firm size have a moderate influence in explaining the firm value variable. Meanwhile, the R-Square value for capital structure is 0.139 , where the variables of financial flexibility, managerial ownership, and firm size are simultaneously able to explain the capital structure variable by $13 \%$ and the remaining $87 \%$ is explained by other variables not included in the model. The RSquare value obtained by the capital structure is in the weak category.

\section{Hypothesis testing}

The hypothesis testing of this study was carried out using SmartPLS (Partial Least Square) 3.0 software. However, the values can be seen from the bootstrapping results and the rule of thumb used in this study is t-statistic $>1.96$ with a significance level of p-value $0.05(5 \%)$.

Table 4. Testing of Hypothesis

\section{Direct Influence}

\begin{tabular}{|c|c|c|c|c|}
\hline Variable relationship path & Original Sample & $\begin{array}{c}\text { T Statistics } \\
(|\mathrm{O} / \mathrm{STDEV}|)\end{array}$ & P Values & Conclusion \\
\hline $\mathrm{X} 1->\mathrm{Y}$ & $-0,168$ & 3,525 & 0,000 & Significant \\
\hline $\mathrm{X} 1->\mathrm{Z}$ & $-0,019$ & 0,338 & 0,735 & Not significant \\
\hline $\mathrm{X} 2->\mathrm{Y}$ & 0,055 & 0,997 & 0,319 & Not significant \\
\hline $\mathrm{X} 2->\mathrm{Z}$ & $-0,091$ & 2,236 & 0,026 & Significant \\
\hline $\mathrm{X} 3->\mathrm{Y}$ & 0,055 & 0,551 & 0,582 & Not significant \\
\hline $\mathrm{X} 3->\mathrm{Z}$ & 0,357 & 6,292 & 0,000 & Significant \\
\hline $\mathrm{Z}->\mathrm{Y}$ & 0,689 & 3,964 & 0,000 & Significant \\
\hline
\end{tabular}

Source: SmartPLS data processing result, 2021 
Indirect Influence

\begin{tabular}{|c|c|c|c|c|}
\hline Variable relationship path & $\begin{array}{c}\text { Original } \\
\text { Sample }\end{array}$ & T Statistics $(|\mathrm{O} / \mathrm{STDEV}|)$ & P Values & Conclusion \\
\hline X1 -> Z-> Y & $-0,013$ & 0,036 & 0,719 & Not significant \\
\hline X2 -> Z-> Y & $-0,063$ & 2,044 & 0,041 & Significant \\
\hline X3 -> Z-> Y & 0,246 & 3,494 & 0,001 & Significant \\
\hline
\end{tabular}

Source: SmartPLS data processing result, 2021

Table 4 results bootstrapping smartPLS shows that :

1. Financial flexibility has no significant effect with negative path coefficient on Capital Structure. The results show a $\mathrm{P}$ value of $0.735>0.05$, a Tstat value of $0.338<1.96$ and original sample is $-0,019$. This proves that financial flexibility has no significant negative effect on capital structure, hence, hypothesis H1: Rejected. It means that companies in the infrastructure, utilities, and transportation sectors rely more on internal funding and choose to used secured debt. The sample in this study are companies from the large-sized infrastructure sector (mature firms) that have enough diverse and sizeable operating cash. So that financial flexibility is not the main consideration in determining the company's capital structure policy.

2. Managerial ownership has a significant effect with negative path coefficient on capital structure. The results showed a $\mathrm{P}$ value of $0.026<0.05$, a Tstat value of $2.236>1.96$, a original sample is 0,091 and this proves that managerial ownership has a significant negative effect on capital structure, therefore, hypothesis H2: Accepted. It means that companies whose shares are partially owned by management tend to apply a low debt policy. Because the management also bears the cost of capital borne by the company and the management will also risk using the debt. So the high managerial ownership will reduce the capital structure.

3. Firm size has a significant effect with positive path coefficient on capital structure. The results show a $\mathrm{P}$ value of $0.000<0.05$, a Tstat value of $6.292>1.96$ and original sample is 0,357 . This proves that the firm size has a significant positive effect on the capital structure, therefore, hypothesis H3: Accepted. It means Large companies will take advantage of the opportunity from the size of their total wealth to increase their capital structure by seeking external funding sources in the form of debt.

4. Financial flexibility has a significant effect with negative path coefficient on firm value. The results show a $\mathrm{P}$ value of $0.000<0.05$, a Tstat value of $3.525>1.96$ and original sample is $-0,168$. This proves that financial flexibility has a significant negative effect on firm value, hence, hypothesis H4: Accepted. It means that an increase in the marginal value of cash can eliminate investment opportunities and then decrease the firm value

5. Managerial ownership has no significant effect with positive path coefficient on firm value. The test results obtained a P-value of $0.319>0.05$, a Tstat value of $0.997<1.96$ and original sample is 0,055 . This proves that managerial ownership has no significant positive effect on firm value, therefore, hypothesis H5: Rejected. It means this study can be said that managerial ownership has not been able to reduce agency problems. The large proportion of managerial ownership cannot equalize the interests of management and shareholders so that the company's goals in achieving high corporate value cannot be achieved.

6. Firm size has no significant effect with positive path coefficient on firm value. The results show that the P-value is $0.582>0.05$, aTstat value is $0.551<1.96$ and original sample is 0,055 . This proves that firm size has no significant positive effect on firm value, therefore, hypothesis H6: Rejected. It means investors in investing do not see the size of the company. It shows that the large size of the company or the size of the company's assets cannot attract investors to give their funds to the company so that it does not affect firm value. 
7. Capital structure has a significant effect with positive path coefficient on firm value. The result shows that the P-value is $0.582>0.05$, the Tstat value is $0.551<1.96$ and original sample is 0,689 . This proves that the capital structure has a significant positive effect on firm value, therefore, hypothesis H7: Accepted. It means that the higher the capital structure, the higher the firm value. It is following the trade-off theory, which states that if the company's debt is large, the value and stock price will increase

8. Financial flexibility has no significant effect with negative path coefficient on firm value through capital structure. The test results show that the value obtained is a $\mathrm{P}$ value of $0.719>0.05$, a Tstat value of $0.036<1.96$ and original sample is $-0,013$. This proves that financial flexibility has no significant neative effect on firm value through capital structure, hence, hypothesis H8: Rejected. Thus, it can be stated that the capital structure cannot function as an intervening variable in the effect of financial flexibility on firm value.

9. Managerial ownership has a significant effect with negative path coefficient on firm value through capital structure. The test results show that the value obtained is a $\mathrm{P}$ value of $0.041<0.05$, a Tstat value of $2.055<1.96$ and original sample is $-0,063$. This proves that managerial ownership has a significant negative effect on firm value through capital structure, therefore, hypothesis H9: Accepted. Thus, it can be stated that the capital structure can function as an intervening variable in the influence of managerial ownership on firm value.

10. Firm size has a significant effect with positive path coefficient on firm value through capital structure. The results show that the P-value is $0.001<0.05$, the Tstat value is $3.494<1.96$ and original sample is 0,246 . This proves that firm size has a significant positive effect on firm value through capital structure, therefore, hypothesis H10: Accepted. Thus, it can be stated that the capital structure can function as an intervening variable in the influence of firm size on firm value.

\section{CONCLUSION}

Financial flexibility has no significant negative effect on capital structure as the results showed that companies with higher financial flexibility will not cause changes in the capital structure. Managerial ownership has a significant negative effect on capital structure. The result indicated that infrastructure, utility, and transportation companies whose shares are partially owned by management tend to apply a low debt policy. Firm size has a significant positive effect on capital structure as the result showed that the larger the firm size, the greater the tendency to use debt for funding. Financial flexibility has a significant negative effect on firm value. The results indicated that the higher the financial flexibility, the firm value will decrease. Managerial ownership has no significant positive effect on firm value as the results showed that an increase in managerial ownership does not necessarily increase firm value. Firm size has no significant positive effect on firm value.

The results indicated that the firm size cannot attract investors to save their funds in the company, therefore it will not affect the firm value. Capital structure has a significant positive effect on firm value as the results showed that the higher the capital structure, the higher the firm value. Financial flexibility has no significant negative effect on firm value through capital structure as the results indicated that increasing financial flexibility through the capital structure will not affect firm value. Managerial ownership has a significant negative effect on firm value through capital structure. The result showed that an increase in the level of managerial ownership reduces the firm value through the capital structure. Also, the firm size has a significant positive effect on firm value through the capital structure. The result indicated that the firm size increases the proportion of capital structure which leads to an increase in the firm value.

\section{ACKNOWLEDGMENTS}

The authors are grateful to all parties who have contributed to this research, so that this research can be carried out properly. 


\section{REFERENCES}

[1] Andriza, R., \& Yusra, I. (2019). Pengaruh kepemilikan manajerial dan kebijakan deviden terhadap kemakmuran Investor dan nilai perusahaan yang tercatat pada indeks LQ45.

[2] Angga Pratama, A. B., \& Wiksuana, I. G. B. (2018). Pengaruh Firm Size Dan Profitabilitas Terhadap Nilai Perusahaan Dengan Struktur Modal Sebagai Variabel Mediasi. E-Jurnal Ekonomi Dan Bisnis Universitas Udayana, 5, 1289. https://doi.org/10.24843/eeb.2018.v07.i05.p03

[3] Aribowo, H., \& Wirapraja, A. (2018). Strategi Inovasi Dalam Rangka Menjaga Keberlanjutan Bisnis Dalam Menghadapi Era Volatility, Uncertainty, Compelxity, Dan Ambiguity (Vuca). Jurnal Ilmu Manajemen Dan Akuntansi Terapan (Jimat), 9(1), 51-58.

[4] Baldwin, R., \& Di Mauro, B. W. (2020). Economics in the time of COVID-19: A new eBook. VOX CEPR Policy Portal, 2-3.

[5] Bilyay-Erdogan, S. (2020). Does financial flexibility enhance firm value? A comparative study between developed and emerging countries. Business: Theory and Practice, 21(2), 723-736.

[6] Brigham, E. F. dan J. F. H. (2011). Dasar - Dasar Manajemen Keuangan (Erlangga (ed.); Kesebelas).

[7] Byoun, S. (2007). Financial Flexibility, Firm Size, and Capital Structure. Journal of Economic Literature.

[8] Chin, $\boldsymbol{W} \cdot \boldsymbol{W} \cdot(1998)$. Commentary: Issues and opinion on structural equation modeling. JSTOR.

[9] Gu, Y., \& Yuan, F. (2020). Internal control, financial flexibility and corporate performance - Based on empirical analysis of listed companies in information Technology industry. Journal of Physics: Conference Series, 1607(1). https://doi.org/10.1088/1742-6596/1607/1/012118

[10] Husnan, S. (2014). Manajemen Keuangan Teori dan Penerapan (KeputusanJangka Panjang). In Edisi Keempat Yogyakarta: BPFE (Edisi Keem). BPFE.

[11] Huy, Q. (2020). Four Strategic Priorities for the Post-COVID-19 World, knowledge.insead.edu. Retrieved from https://knowledge.insead.edu/blog/insead-blog/four-strategic-priorities-for-thepost-covid-19-world14086

[12] KataData. (2021, 10 7). Saham Garuda Anjlok 40\%, Chairul Tanjung Diklaim Rugi Rp 11 T Retrieved 2021 from katadata.co.id https://katadata.co.id/lavinda/finansial /60bdd68904ba2^saham-garuda-anjlok-40chairul-tanjung-diklaim-rugi-rp-11-t:

[13] Keown, A. J. (2010). Basic Financial Management, Diterjemahkan oleh Chaerul D. Djakman. Salemba Empat.

[14] Lumapow, L. S. (2018). The Influence of Managerial Ownership and Firm Size On Debt Policy. International Journal of Applied Business and International Management, 3(1), 47-55.

[15] Martono, dan Harjito, D. A. (2005). Manajemen Keuangan (Pertama). Ekonisia Fakultas Ekonomi UI.

[16] Pramana, I., \& Mustanda, I. (2016). The Effect of Profitability and Size on Firm Value with CSR as a moderating variable. E-Journal of Management, 5(1), 27-33. https://doi.org/10.9790/487X-2204062733

[17] Sudana, M. I. (2011). Manajemen Keuangan Perusahaan: Teori dan Praktik. Erlangga.

[18] Teng, X., Chang, B.-G., \& Wu, K.-S. (2021). The Role of Financial Flexibility on Enterprise Sustainable Development during the COVID-19 Crisis-A Consideration of Tangible Assets. In Sustainability (Vol. 13, Issue 3). https://doi.org/10.3390/su13031245

[19] Wright, S. (1934). The Method of Path Coefficients. The Annals of Mathematical Statistics, 5(3), 161-215. http://www.jstor.org/stable/2957502 